\title{
Assessment of Neural Precursor Cell Expressed Developmentally Down- Regulated Protein 4 Gene Transcript Variant 3 Expression and Insulin- Like Gross Factor -1 in Keloid Tissue
}

\author{
A.M.Alrefai ${ }^{1}$, N. E.Srour ${ }^{1}$, N.F. Al- Husseini ${ }^{2}$ and M. S. Abd-Elsayed ${ }^{1}$ \\ ${ }^{1}$ Dermatology, Venereology and Andrology Dept., Faculty of Medicine, Benha Univ., Benha, Egypt \\ ${ }^{2}$ Biochemistry and Molecular Biology Dept., Faculty of Medicine, Benha Univ., Benha, Egypt \\ E-Mail: mariansameh86@yahoo.com
}

\begin{abstract}
Keloids are considered as favorable fibro-proliferative skin tumors developing past the site of the first dermal injury. Neural forerunner cell communicated formatively down-controlled protein 4 (NEDD4) is an E3 ubiquitin ligase catalyst that objectives proteins for ubiquitination. In this investigation, it was intended to survey Neural Precursor Cell Expressed Developmentally Down-Regulated Protein 4 Gene Transcript Variant 3(NEDD4 TV3) and Insulin-like Gross Factor - 1 (IGF-1) in patients with dynamic keloid $\leq 6$ months length. The examination included 40 patients of keloids and 20 subjects of coordinated age, sex and weight file (BMI). There was critical positive relationship between's NEDD4TV-3 and IGF quality articulation. This information add novel angles to the part of NEDD4 TV3 in the advancement of keloid.
\end{abstract}

Key words: Keloid, NEDD4 TV3.

\section{Introduction}

The keloids were initially considered as obsessive injury recuperating measure. Considered as considerate tumors, keloids were uncontrolled and unconfined forcefully limited hyperplasia of dermal connective tissues emerging from an anomalous injury mending measure. This favorable sore frequently follows dermal injury, consume injury, inking and even basic acnes. Familial inclination and more obscure skin races inclination were seen in commonness of this kindhearted sickness [1].

Keloids mark an interminable incendiary sickness portrayed by a fibroproliferative issue of the skin. The genone polymorphism of Neural Precursor Cell Expressed Developmentally DownRegulated Protein 4 Gene Transcript Variant 3 quality demonstrated six protein-coding record variations (TVs), is hereditarily connected to keloids. The high recurrence of danger allele $\mathrm{C}$ in rs8032158 in keloid patients is related with a specifically higher articulation of TV3 of (NEDD4) to initiate the NF-kB pathway [2].

Hereditary examinations have given proof to a hereditary inclination to keloid development and a keloid hazard allele has been accounted for in the quality locus for the E3 ubiquitin ligase NEDD4 [3].

The Neural Precursor Cell Expressed Developmentally Down-Regulated Protein 4 Gene Transcript Variant 3 (NEDD4) quality comprises of 30 exons that produce six protein-coding TVs (TV1e5 and TV7). The part of Neural Precursor Cell Expressed Developmentally Down-Regulated Protein 4 Gene Transcript Variant 3(NEDD4 TV3) in pathogenesis of keloid has not been explained. Steady with past Genomic Wide Association Study (GWAS) reports, hazard allele C was substantially more continuous in keloid patients than in sound volunteers [2].
There are biomarkers identified with development factors, for example, (PDGF) plateletdetermined development factor (PDGF) insulinlike development factor-1(IGF-1) fibroblast enactment protein-alpha (FAP- $\alpha)$ and connective tissue development factor (CTGF). Such potential biomarkers assume key functions in keloid development, enactment of fibroblasts, enlistment of extracellular lattice (ECM) affidavit and collagen creation [4].

There was raised articulation of various IGFauthoritative and IGF-restricting related proteins [5].

The point of this investigation was to evaluate Neural Precursor Cell Expressed Developmentally Down-Regulated Protein 4 Gene Transcript Variant 3(NEDD4 TV3) and Insulin-like Gross Factor - 1 (IGF-1) in patients with dynamic keloid $\leq 6$ months length.

\section{Patients and methods}

This is a cross Section case control study .The investigation included 40 patients of keloids and 20 subjects of coordinated age, sex and weight list (BMI) going to the dermatology outpatient center at Benha University Hospital, Benha, Egypt from June 2019 to June 2020.

Members gave their educated composed assent before enlistment and the investigation was endorsed by the Research Ethics Committee in Faculty of Medicine, Benha University.

All patients remembered for the investigation have clinically affirmed finding of keloid with term $\leq$ a half year. Patients with skin infection other than keloids ,Pregnant and lactating patients, and subjects with malignancies, immune system issues, hepatic or renal ailments were rejected.

\section{Laboratory investigations}

About $4 \mathrm{~mm}$ punch biopsies were taken from each subject and promptly put in fluid nitrogen to 
be put away at $-80^{\circ} \mathrm{C}$ for additional testing of Neural Precursor Cell Expressed Developmentally Down-Regulated Protein 4 Gene Transcript Variant 3 and Insulin-Like Gross Factor - 1 in Keloid Tissue by PCR the genome was removed and tried.

\subsection{Statistical analysis}

Statistical analysis was performed using the Statistical Package for Social Sciences (SPSS) vs.25. Mean $\pm \mathrm{SD}$, t test, Mann Whitney test, Chi square test, Pearson test, Kruskal Wallis test, ROC and AUC, were used.

\section{Results \\ 1- Demographic criteria}

The age and sex were matched between the cases and control groups Table (1).

Table (1) Demographic criteria of the studied groups.

\begin{tabular}{|c|c|c|c|c|c|c|c|}
\hline \multicolumn{2}{|c|}{ Variable } & \multicolumn{2}{|c|}{$\begin{array}{l}\text { Keloid patients } \\
\qquad(\mathrm{N}=\mathbf{4 0})\end{array}$} & \multicolumn{2}{|c|}{$\begin{array}{c}\text { Controls } \\
(\mathbf{N}=20)\end{array}$} & $\begin{array}{c}\text { Test of } \\
\text { significance }\end{array}$ & $\mathbf{P}$ \\
\hline \multirow{3}{*}{$\begin{array}{l}\text { Age } \\
(y s)\end{array}$} & Mean \pm SD & & & & & \multirow{3}{*}{$\begin{array}{l}\text { St."t"= } \\
0.43\end{array}$} & \multirow{3}{*}{$\begin{array}{l}0.88 \\
(\mathrm{NS})\end{array}$} \\
\hline & Range & & & & & & \\
\hline & & No. & $\%$ & No. & $\%$ & & \\
\hline \multirow{2}{*}{ Sex } & Male & 34 & 74 & 17 & 80.0 & $\chi^{2}=$ & 0.75 \\
\hline & Females & 7 & 26 & 3 & 20.0 & 0.04 & (NS) \\
\hline
\end{tabular}

2- Comparing the studied groups regarding NEDD4TV-3 gene expression

There was a highly significant difference between the 2 groups regarding NEDD4TV-3 gene expression Table (2).

\begin{tabular}{lcccccc}
\hline & \multicolumn{2}{c}{ Patients (No.=40) } & \multicolumn{2}{c}{ Controls (No.=20) } & Z $_{\text {MwU }}$ test & P-value \\
\hline \multirow{2}{*}{ NEDD4TV-3 } & Mean & SD & Mean & SD & & \\
& 204865.4 & 34180.3 & $65711 . .2$ & 12937.9 & 5.06 & $<0.001$ \\
\hline
\end{tabular}

\section{Discussion}

Keloid is characterized as a scar inside the skin that develops past the bounds of unique injury. Numerous variables, for example, skin strain, wound contamination, racial contrast and hereditary inclination have been embroiled in the etiology of keloid injuries [6].

NEDD4 was recently distinguished as one of the qualities liable for keloid, yet the related pathogenesis stays hazy. NEDD4 encodes an E3 ubiquitin ligase that has a HECT area and is associated with ubiquitin-interceded protein corruption [7]. Insulin-like development factor-I (IGF-I) is a peptide development factor that applies mitogenic and metabolic exercises that are controllers of development, endurance and cell separation in various cell and tissue types [8].

The aggravation intensifier is unequivocally actuated in the keratinocytes and fibroblasts of keloid tissue in a NEDD4 TV3-subordinate way. Unthinkingly, NEDD4 TV3 unequivocally collaborated with the connector protein RIP to actuate NF- $\mathrm{NB}[2]$.

IGF quality is fibrogenetic and provocative elements assume a part in its pathogenesis including skin break out hypertrophic scar arrangement [9].

\section{Conclusion}

NEDD4TV-3 and IGF quality articulations are related with the defenselessness of advancement of keloid.

\section{Financial support and sponsorship Nil.}

\section{Conflicts of interest}

Ther are no conflicts of interest

\section{Reference}

[1] K.G., Bennett, T.A., Kung, J.A. Hayman, D.L. Brown, Treatment of keloids with excision and adjuvant radiation: a single center experience and review of the literature. Annals of plastic surgery, Vol.78(2), PP.157-161, 2017.

[2] M. Fujita, Y. Yamamoto, J.J. Jiang, T. Atsumi, Y. Tanaka, T. Ohki, N. Murao, E. Funayama, T.Hayashi, M. Osawa, T. Maeda, NEDD4 is involved in inflammation development during keloid formation. Journal of Investigative Dermatology, Vol.139(2), PP.333-341, 2019.

[3] A.G. Marneros, A Role for the E3 Ubiquitin Ligase NEDD4 in Keloid Pathogenesis. Journal of Investigative Dermatology, Vol.139(2), PP.279-280, 2019. 
[4] S. Kang, J. K. Hur, D. Kim, Advances in diagnostic methods for keloids and biomarkertargeted fluorescent probes. Analyst, Vol.144(6), PP.1866-1875, 2019.

[5] J. Wang, Y.C Li, M. Deng, H. Y. Jiang, L. H. Guo, W. J. Zhou, B. Ruan, Serum insulin-like growth factor-1 and its binding protein 3 as prognostic factors for the incidence, progression, and outcome of hepatocellular carcinoma: a systematic review and metaanalysis. Oncotarget, Vol.8(46), P.81098, 2017.

[6] H. Shimizu, R. Ghazizadeh, M. Ghazizadeh, Experimental and Clinical Research. Am J Exp Clin Res, 6(2), pp.337-340, 2019.

[7] S. Chung, M. Nakashima,H. Zembutsu, Y. Nakamura, Possible involvement of NEDD4 in keloid formation; its critical role in fibroblast proliferation and collagen production.
Proceedings of the Japan Academy, Series B, Vol.87(8), PP.563-573, 2011.

[8] F. Canzian, J.D. McKay, R.J. Cleveland, L. Dossus, C. Biessy, S. Rinaldi, S. Landi, C. Boillot, S. Monnier, V. Chajes, F. ClavelChapelon, Polymorphisms of genes coding for insulin-like growth factor 1 and its major binding proteins, circulating levels of IGF-I and IGFBP-3 and breast cancer risk: results from the EPIC study. British journal of cancer, Vol.94(2), PP.299-307, 2006.

[9] J. H. Yang, J. Y. Yoon, J. Moon, S. Min, H. H. Kwon, D. H. Suh, Expression of inflammatory and fibrogenetic markers in acne hypertrophic scar formation: focusing on role of TGF- $\beta$ and IGF-1R. Archives of Dermatological Research, Vol.310(8), PP.665-673, 2018. 